\title{
Visual Analog Scale (50 mm)
}

National Cancer Institute

\section{Source}

National Cancer Institute. Visual Analog Scale $(50 \mathrm{~mm})$. NCl Thesaurus. Code C158269.

A type of visual analog scale composed of a $50 \mathrm{~mm}$ vertical or horizontal line. 